6 Department of Health and Social Security and Office of Population Censuses and Surveys. Hospital in-patient enquiry for England 1985. London: HMSO, 1987. (Series MB4 No 27 .)

7 Department of Health and Social Security. On the state of the public health for the year 1986. London: HMSO, 1987.

8 Schofield M. The sexual behaviour of young people. London: Longman, 1965.

8 Schofield M. The sexual behaviour of young people. London. Longman, 1965.

9 Schold M. The sexual behaviour of young paluts. Lond All Lane, 1973. Provisional data from the RUHBC CATI survey. Research Unit in Health Provisional data from the RUHBC CATI survey. Research Unit in Heal and Behavioural Change. Edinburgh: April 1988. (RUHBC report No 2.)

11 United Kingdom Family Planning Research Network. Patterns of sexual behaviour among sexually experienced women attending family planning clinics in England, Scotland and Wales. British Jourmal of Family Planning 1988; 14:74-82.

12 Department of Health. Short-term prediction of HIV infection and AIDS in England and Wales. London: HMSO, 1988.

3 Belsey EM, Adler MW. Study of STD clinic attenders in England and Wales. British Joumal of Venereal Disease 1981;57:285-9.
14 Kinsey AC, Pomeroy WB, Martin CE. Sexual behaviour in the human male. Philadelphia: Saunders, 1949.

15 Gebhard PH, Johnson AB, eds. The Kinsey data: marginal tabulations of the 1938-1963 interviews conducted by the Institute for Sex Research. Philadelphia: Saunders, 1979.

16 Fay RE, Turner CF, Klassen AD, Gagnon JH. Prevalence and patterns of same gender sexual contact among men. Science 1989;243:338-48.

17 Peto J. AIDS and promiscuity. Lancet 1986;ii:979.

18 Buckley JD, Harris RWC, Doll R, Vessey MP, Williams PT. Case-control study of the husbands of women with dysplasia or carcinoma of the cervix uteri. Lancet 1981 ;ii:1010-5.

19 Rotkin ID. Etiology and epidemiology of cervical cancer. In: DallenbachHellwegg, ed. Current topics in pathology-cervical cancer. Berlin: SpringerVerlag, 1981:81-110.

20 Mant D, Vessey $M$, Loudon N. Social class differences in sexual behaviour and cervical cancer. Community Med 1988;10:52-6.

(Accepted 14 February 1989)

\title{
Effects of fibrinolytic inhibitors on mortality from upper gastrointestinal haemorrhage
}

\author{
David A Henry, Dianne L O’Connell
}

University of Newcastle, Newcastle, New South Wales 2308, Australia

David A Henry, FRCP, senior lecturer in clinical pharmacology, faculty of medicine

Dianne L O'Connell, PHD, lecturer in biostatistics, centre for clinical epidemiology and biostatistics

Correspondence to: $\mathrm{Dr}$ Henry.
Abstract

Objective-To see whether fibrinolytic inhibitors are of value when given to patients with upper gastrointestinal haemorrhage.

Design-Meta-analysis of six randomised double blind placebo controlled trials. Two methods used for obtaining an overall estimate of effect, including a random effects model incorporating any heterogeneity of outcome in the estimate of the overall treatment effect.

Setting-Inpatient care in hospitals in the United Kingdom, Sweden, and Australia.

Patients - 1267 Patients admitted to hospital with primary diagnosis of acute upper gastrointestinal haemorrhage. Five of the six trials included a high proportion of elderly patients. Most patients were bleeding from peptic ulcers in the stomach and duodenum (43-88\%) or gastric erosions (4-23\%). A variable proportion had a degree of clinical shock at entry.

Interventions-Tranexamic acid 3-6 g/day given intravenously for two or three days followed by 3-6 g/ day by mouth for a further three to five days (four trials) or 4-5-12 g/day by mouth for two to seven days (two trials).

End points-Frequency of recurrent haemorrhage, need for surgery, and death.

Main results-Treatment with tranexamic acid was associated with a $20-30 \%$ reduction in the rate of rebleeding, a $30-40 \%$ reduction in the need for surgery, and a $40 \%$ reduction (95\% confidence interval $10 \%$ to $60 \%$ ) in mortality.

Conclusions-Treatment with tranexamic acid may be of value to patients considered to be at risk of dying after an upper gastrointestinal haemorrhage.

haemorrhage have individually been too small to assess the effects on mortality.

This failure to test rigorously the candidate medical treatments for upper gastrointestinal haemorrhage is disappointing. Clinical trials are fairly straightforward, as most deaths occur within a week or two of the initial bleed and any benefits will be apparent after a short course of treatment. In the absence of definitive studies meta-analysis, which reviews critically the available clinical trials, assesses the homogeneity of any treatment effects, and pools the data to obtain an overall measure of benefit, may be valuable. ${ }^{4}$ Collins and Langman have reported a meta-analysis of randomised controlled trials of histamine $\mathrm{H}_{2}$ antagonists in upper gastrointestinal haemorrhage, which showed that treatment was associated with a modest reduction in the frequency of rebleeding, need for operation, and mortality and that benefit was most pronounced in patients bleeding from gastric ulcers.

The antifibrinolytic drug tranexamic acid was first tested in a randomised clinical trial for upper gastrointestinal haemorrhage in $1973 .^{\circ}$ Despite early claims of benefit, ${ }^{67}$ the drug does not appear to be widely used. For instance, the extensive survey of upper gastrointestinal haemorrhage published by the American Society for Gastrointestinal Endoscopy in 1982, which included a review of drug treatments employed by gastroenterologists in the United States, made no mention of fibrinolytic inhibitors. ${ }^{8}$ It was uncertainty about the role of fibrinolytic inhibitors that prompted this study.

The specific purpose of this study was to review and combine the results of all valid randomised controlled clinical trials in order to obtain an overall measure of the possible benefits of the use of fibrinolytic inhibitors in terms of reduced rates of rebleeding, emergency surgery, and death in patients admitted to hospital with a primary diagnosis of upper gastrointestinal haemorrhage.

Pharmacological treatments that have been tested in upper gastrointestinal haemorrhage, such as antacids, histamine $\mathrm{H}_{2}$ receptor antagonists, and fibrinolytic inhibitors, have theoretical appeal. Candidate drugs are cheap and comparatively safe and if they proved effective they could be given to most patients with this condition, including the many who are not looked after by specialists. The efficacy of drug treatment, however, has not been adequately evaluated. ${ }^{1}$ Survival is the most important measure of the success of management in upper gastrointestinal haemorrhage. In contrast with the extensive evaluation of $\beta$ adrenoceptor blockade or fibrinolysis after myocardial infarction, ${ }^{23}$ the trials of drug treatment in upper gastrointestinal

\section{Methods}

LIBRARY SEARCH

A Medline search (key words aminocaproic acids, tranexamic acid, haemorrhage, gastrointestinal) back to 1971 was supplemented by a manual search of the Index Medicus back to 1967 and a manual search of the Iowa Drug Information Service drug literature microfilm file back to 1977. Bibliographies of relevant articles, including published trials and general reviews of fibrinolytic inhibitors, were also used as sources of information. A manufacturer of fibrinolytic inhibitors 


\begin{tabular}{|c|c|c|c|c|c|c|}
\hline Authors & $\begin{array}{l}\text { Total No of } \\
\text { patients }\end{array}$ & $\begin{array}{l}\text { Age distribution } \\
\text { (years) }\end{array}$ & Exclusion criteria & $\begin{array}{l}\text { No (\%) of patients } \\
\text { with some } \\
\text { degree of } \\
\text { clinical shock }\end{array}$ & $\begin{array}{l}\text { Mode of } \\
\text { diagnosis }\end{array}$ & $\begin{array}{l}\text { Sources of haemorrhage (proportion of } \\
\text { patients bleeding from specific sites } \dagger \text { ) }\end{array}$ \\
\hline Cormack et al (1973) & 150 & $88(59 \%)$ Aged $>60$ & Known terminal diseases & $16(11)$ & Radiography & $\begin{array}{l}125(83 \%) \text { Patients had peptic ulcers or } \\
\text { erosions. Further details not provided }\end{array}$ \\
\hline Biggs et al (1976) & 200 & $67(34 \%)$ Aged $>60$ & $\begin{array}{l}\text { Pregnancy, chronic renal impairment, previous } \\
\text { vascular surgery, thromboembolic evènt } \\
\text { within preceding } 12 \text { months }\end{array}$ & $45(23)$ & $\begin{array}{l}\text { Endoscopy and } \\
\text { radiography }\end{array}$ & $\begin{array}{l}\text { Peptic ulcer } 108(54 \%) \text {, erosions } 46(23 \%) \text {, } \\
\text { oesophageal } 26(13 \%) \text {, other } \ 20(10 \%)\end{array}$ \\
\hline Engqvist et al $(1979)^{\circ}$ & 149 & Mean age $57 \cdot 6$ & Renal failure, history of thrombosis & “All” & $\begin{array}{l}\text { Endoscopy and } \\
\text { radiography }\end{array}$ & $\begin{array}{l}\text { Peptic ulcer } 83(43 \%) \text {, erosions } 31(16 \%) \text {, } \\
\text { oesophageal } \$ 30(16 \%) \text {, other } \$ 47(25 \%)\end{array}$ \\
\hline Bergqvist et al $(1980)^{10}$ & $43(50) \|$ & Mean age $59 \cdot 2$ & None stated & $27(63)$ & $\begin{array}{l}\text { Endoscopy and } \\
\text { radiography }\end{array}$ & $\begin{array}{c}\text { Peptic ulcer } 28(65 \%) \text {, erosions } 8(19 \%) \text {, } \\
\text { oesophageal } 3(7 \%) \text {, other } \$ 4(9 \%)\end{array}$ \\
\hline Barer et al (1983)" & 516 & Mean age 61.7 & $\begin{array}{l}\text { Need for immediate surgery, coexisting severe } \\
\text { medical problems, trivial bleeding }\end{array}$ & $69(13)$ & Endoscopy & $\begin{array}{l}\text { Peptic ulcer } 250(56 \%) \text {, erosions } 36(8 \%) \text {, } \\
\text { oesophageal } \text { and other\ } 158(36 \%)\end{array}$ \\
\hline $\begin{array}{l}\text { Stael von Holstein et al } \\
\quad(1987)^{13}\end{array}$ & $154(202)$ & Mean age $64 \cdot 0$ & $\begin{array}{l}\text { Thromboembolic disease, bleeding or } \\
\text { coagulation defects, pregnancy, patients who } \\
\text { had not bled from benign lesion of stomach or } \\
\text { duodenum }\end{array}$ & $21(14)$ & Endoscopy & $\begin{array}{l}\text { Peptic ulcer } 135(88 \%) \text {, erosions } 6(4 \%), \\
\text { oesophageal } 5 \text { (3\%), other } \$ 8(5 \%)\end{array}$ \\
\hline
\end{tabular}

*"Clinical shock" variously described as: condition "poor" at entry (Cormack et al $\left.l^{6}\right)$; estimated blood loss more than 1 litre $($ Biggs $e t$ al'); systolic blood pressure $<100 \mathrm{~mm} \mathrm{Hg}$ or pulse $>100 /$ min or estimated blood loss $>1800 \mathrm{ml}$ or fall in haemoglobin concentration $\geqslant 30 \mathrm{~g} / \mathrm{l}$ in first two days (Engqvist $e$ a $\left.a l^{\circ}\right)$; requiring immediate infusion of dextran 70 at entry $\left(\right.$ Bergqvist $e t$ a $\left.l^{10}\right)$; systolic blood pressure $<100 \mathrm{~mm} \mathrm{Hg}\left(\right.$ Barer et al $\left.l^{\prime \prime}\right)$; "unstable circulation"( Stael von Holstein et al $^{13}$ ).

†In two trials totals differ from those in second column of this table. In the trial of Engqvist $e t$ a $l^{9}$ patients were described as bleeding from more than one lesion. In the trial of Barer $e t a l^{\prime \prime}$ site of haemorrhage were described only for patients who completed treatment.

†Includes oesophageal varices, oesophagitis, and Mallory-Weiss tears.

$§$ Includes patients in whom bleeding sites could not be identified.

\|Numbers in parentheses include patients withdrawn after randomisation, for whom additional information was provided by principal authors.

TABLE II-Details of randomised placebo controlled trials of tranexamic acid in upper gastrointestinal haemorrhage

\begin{tabular}{|c|c|c|c|}
\hline \multirow[b]{2}{*}{ Authors } & \multirow[b]{2}{*}{ Treatment regimen } & \multicolumn{2}{|c|}{ Reporting of end points in trials } \\
\hline & & Criteria of rebleeding & Indications for operation \\
\hline Cormack et al $(1973)^{\circ}$ & $4.5 \mathrm{~g} /$ day by mouth for 7 days & Severe enough to require retransfusion & $\begin{array}{l}\text { Not stated. Included in definition of "treatment } \\
\text { failure" }\end{array}$ \\
\hline Biggs et al (1976)? & $\begin{array}{l}3 \mathrm{~g} / \text { day intravenously plus } \\
3 \mathrm{~g} / \text { day by mouth for } 2 \text { days } \\
\text { followed by } 3 \mathrm{~g} / \text { day by } \\
\text { mouth for } 3 \text { days }\end{array}$ & Severe enough to require surgery & $\begin{array}{l}\text { Not stated. Most operations were for continued or } \\
\text { recurrent bleeding }\end{array}$ \\
\hline Engqvist et al $(1979)^{9}$ & $\begin{array}{l}6 \mathrm{~g} / \text { day intravenously for } 3 \\
\text { days followed by } 6 \mathrm{~g} / \text { day by } \\
\text { mouth for } 4 \text { days }\end{array}$ & Not stated & $\begin{array}{l}\text { Difficulty in compensating for continuous bleed } \\
\text { during first } 6 \text { hours or continued bleeding requiring } \\
\text { transfusion of }>6 \text { units blood }\end{array}$ \\
\hline Bergqvist et al $(1980)^{10}$ & $12 \mathrm{~g} /$ day by mouth for 2 days & Severe enough to require surgery & $\begin{array}{l}\text { Not stated. Most operations were for continued or } \\
\text { recurrent bleeding }\end{array}$ \\
\hline Barer et al (1983)" & $\begin{array}{l}4 \mathrm{~g} / \text { day intravenously for } 2 \\
\text { days followed by } 4 \mathrm{~g} / \text { day by } \\
\text { mouth for } 5 \text { days }\end{array}$ & $\begin{array}{l}\text { Severe haematemesis or fresh melaena } \\
\text { after admission or unexplained fall of } \\
\geqslant 20 \mathrm{~g} / \mathrm{l} \text { in haemoglobin within any } 24 \\
\text { hour period }\end{array}$ & $\begin{array}{l}\text { Not stated. Most operations were for continued or } \\
\text { recurrent bleeding }\end{array}$ \\
\hline $\begin{array}{l}\text { Stael von Holstein } \text { et al } \\
(1987)^{13}\end{array}$ & $\begin{array}{l}6 \mathrm{~g} / \text { day intravenously for } 3 \\
\text { days followed by } 6 \mathrm{~g} / \text { day by } \\
\text { mouth for } 3 \text { days }\end{array}$ & $\begin{array}{l}\text { Fresh bleeding after "silent" period or } \\
\text { drop in haemoglobin of } \geqslant 20 \mathrm{~g} / 1\end{array}$ & $\begin{array}{l}\text { Severe continuous bleeding; transfusion of }>6 \text { units } \\
\text { blood; signs of rebleeding with unstable circulation }\end{array}$ \\
\hline
\end{tabular}

and the principal authors of published randomised trials were contacted to see if they knew of other published or unpublished work.

Excluding anecdotal reports and an abstract (later published in full), we identified 11 publications describing the use of fibrinolytic inhibitors in upper gastrointestinal haemorrhage. ${ }^{679.17}$ Two case series were uncontrolled. ${ }^{14}$ is One paper was an account of a trial in German, which was subsequently fully reported in English." ${ }^{12}$ A "controlled" clinical trial of tranexamic acid was excluded, as patients were apparently not randomly assigned to treatment. ${ }^{16} \mathrm{~A}$ randomised placebo controlled trial of a "haemostatic solution" containing aminocaproic acid was excluded, as the mixture contained other possibly active compounds (thrombin, atropine, noradrenaline). ${ }^{17}$

In all, six reports described the outcome in a total of 1212 patients admitted to hospital with a primary diagnosis of upper gastrointestinal haemorrhage who entered randomised placebo controlled trials of tranexamic acid. ${ }^{679-1113}$ The reports of three trials did not describe the outcomes in subjects who were withdrawn after randomisation..$^{910}$ In response to a request authors provided further information on 55 subjects entered in two of these trials ${ }^{1{ }^{13}}$ (D Bergqvist, personal communication; S B Eriksson, personal communication). Further details of the third trial could not be obtained.

\section{COMPARABILITY OF PATIENTS AT ENTRY}

Table I gives the details of patients at entry to the six trials. In one trial most patients had bled from lesions in the stomach and duodenum. ${ }^{13}$ In the other studies patients bleeding from oesophageal sites were included. The sex and age distributions of patients differed little except for the trial of Biggs et al, which included a larger proportion of young subjects. ${ }^{7}$ There were differences in the clinical condition of patients at entry. Two trials restricted entry to subjects who had signs of an unstable circulation. ${ }^{910}$ In the other trials $11-23 \%$ of patients had signs of haemodynamic upset, generally defined in terms of the need for urgent resuscitation, an estimated blood loss of over 1 litre, pulse rate or blood pressure changes present on admission, or a fall in the haemoglobin concentration of more than $30 \mathrm{~g} / \mathrm{l}$ in the first two days.

\section{TREATMENT REGIMENS}

All patients were assigned randomly to treatment with tranexamic acid or identical placebo (table II). In four studies tranexamic acid was initially given intravenously in a dose of 3-6 g/day in divided doses followed by 3-6 g/day by mouth for a further three to five days. ${ }^{791113}$ In the other two studies tranexamic acid was given by mouth from the start, in one trial for two days in a dose of $12 \mathrm{~g} /$ day and in the other for seven days in a dose of $4 \cdot 5 \mathrm{~g} /$ day. $^{6}{ }^{6}$

\section{TRIAL END POINTS}

The trial reports, supplemented by information provided by two authors (Bergqvist and Eriksson, personal communications), provided enough detail to assess the impact of treatment on the rate of continued or recurrent haemorrhage, the need for emergency 


\begin{tabular}{|c|c|c|c|c|c|c|c|c|}
\hline \multirow[b]{2}{*}{ Authors } & \multirow{2}{*}{$\begin{array}{l}\text { Study } \\
\text { group }\end{array}$} & \multirow{2}{*}{$\begin{array}{c}\text { No of } \\
\text { patients } \\
\text { randomised }\end{array}$} & \multirow{2}{*}{$\begin{array}{l}\text { No who } \\
\text { rebled }\end{array}$} & \multirow{2}{*}{$\begin{array}{c}\text { No who } \\
\text { had surgery }\end{array}$} & \multirow{2}{*}{$\begin{array}{l}\text { No who } \\
\text { died }\end{array}$} & \multicolumn{3}{|c|}{ Odds ratios ( $95 \%$ confidence intervals) } \\
\hline & & & & & & Rebleeding & Operation & Death \\
\hline Cormack et al $(1973)^{n}$ & $\left\{\begin{array}{l}\text { Treated } \\
\text { Control }\end{array}\right.$ & $\begin{array}{l}76 \\
74\end{array}$ & $\begin{array}{r}8 \\
11\end{array}$ & $\begin{array}{l}\text { NA } \\
\text { NA }\end{array}$ & $\begin{array}{l}3 \\
3\end{array}$ & $0.67(0.22$ to 1.98$)$ & & $0.97(0.13$ to 7.51$)$ \\
\hline Biggs et al (1976) & $\left\{\begin{array}{l}\text { Treated } \\
\text { Control }\end{array}\right.$ & $\begin{array}{r}103 \\
97\end{array}$ & $\begin{array}{r}7 \\
19\end{array}$ & $\begin{array}{r}7 \\
21\end{array}$ & $\begin{array}{l}2 \\
4\end{array}$ & $0.30(0 \cdot 10 \text { to } 0 \cdot 80)^{\star}$ & $0.26(0.09 \text { to } 0.69)^{\star}$ & $0.46(0.04$ to 3.31$)$ \\
\hline Engqvist et al (1979) ${ }^{9}$ & $\left\{\begin{array}{l}\text { Treated } \\
\text { Control }\end{array}\right.$ & $\begin{array}{l}76 \\
73\end{array}$ & $\begin{array}{l}23 \\
29\end{array}$ & $\begin{array}{l}10 \\
18\end{array}$ & $\begin{array}{l}11 \\
12\end{array}$ & $0.66(0.32$ to 1.37$)$ & $0.46(0 \cdot 18$ to $1 \cdot 17)$ & $0.86(0.32$ to 2.31$)$ \\
\hline Bergqvist et al $(1980)^{10}$ & $\left\{\begin{array}{l}\text { Treated } \\
\text { Control }\end{array}\right.$ & $\begin{array}{l}25 \\
25\end{array}$ & $\begin{array}{l}5 \\
4\end{array}$ & $\begin{array}{l}8 \\
7\end{array}$ & $\begin{array}{l}5 \\
6\end{array}$ & $1.31(0.24$ to 7.59$)$ & $1 \cdot 21(0 \cdot 30$ to $4 \cdot 87)$ & $0.79(0.16$ to $3 \cdot 73)$ \\
\hline Barer et al (1983)" & $\left\{\begin{array}{l}\text { Treated } \\
\text { Control }\end{array}\right.$ & $\begin{array}{l}256 \\
260\end{array}$ & $\begin{array}{l}58 \\
51\end{array}$ & $\begin{array}{l}47 \\
40\end{array}$ & $\begin{array}{l}16 \\
35\end{array}$ & $1.20(0.77$ to 1.88$)$ & $1 \cdot 24(0.76$ to 2.02$)$ & $0.43(0.22 \text { to } 0.82)^{\star}$ \\
\hline $\begin{array}{l}\text { Stael von Holstein et al } \\
\quad(1987)^{13}\end{array}$ & $\left\{\begin{array}{l}\text { Treated } \\
\text { Control }\end{array}\right.$ & $\begin{array}{r}94 \\
108\end{array}$ & $\begin{array}{l}11 \\
20\end{array}$ & $\begin{array}{r}5 \\
16\end{array}$ & $\begin{array}{l}4 \\
6\end{array}$ & $0.58(0.24$ to 1.37$)$ & $0.32(0.09 \text { to } 0.98)^{\star}$ & $0.76(0.15$ to 3.31$)$ \\
\hline Total & & 1267 & 246 & 179 & 107 & & & \\
\hline
\end{tabular}

TABLE IV-Results of meta-analyses of randomised trials of tranexamic acid in acute upper gastrointestinal haemorrhage

\begin{tabular}{|c|c|c|c|c|c|c|c|c|}
\hline & \multicolumn{4}{|c|}{ Method of Peto ${ }^{19}$} & \multicolumn{4}{|c|}{ Method of DerSimonian and Laird ${ }^{20}$} \\
\hline & $\begin{array}{l}\text { Pooled } \\
\text { odds ratio }\end{array}$ & $\begin{array}{c}95 \% \\
\text { Confidence } \\
\text { interval }\end{array}$ & $\begin{array}{c}\mathrm{p} \\
\text { Value }\end{array}$ & $\begin{array}{l}\mathrm{p} \text { Value for } \\
\text { heterogeneity }\end{array}$ & $\begin{array}{l}\text { Pooled } \\
\text { odds ratio }\end{array}$ & $\begin{array}{c}95 \% \\
\text { Confidence } \\
\text { interval }\end{array}$ & $\begin{array}{c}\mathrm{p} \\
\text { Value }\end{array}$ & $\begin{array}{l}\mathrm{p} \text { Value for } \\
\text { heterogeneity }\end{array}$ \\
\hline & 0.80 & 0.61 to 1.10 & 0.13 & 0.0 & 0.72 & 0.46 to 1.10 & $0 \cdot 14$ & 0.09 \\
\hline Operation & $0 \cdot 72$ & 0.52 to 1.00 & 0.047 & 0.007 & 0.58 & 0.29 to 1.80 & $0 \cdot 13$ & 0.008 \\
\hline Death & $0 \cdot 60$ & 0.40 to 0.89 & 0.01 & 0.82 & $0 \cdot 60$ & 0.39 to 0.90 & 0.02 & $0 \cdot 78$ \\
\hline
\end{tabular}

surgery, and mortality (table II). In two studies rebleeding was analysed only if it was severe enough to require surgery. ${ }^{10}$ In two other studies rebleeding was defined as fresh haemorrhage or a fall in the haemoglobin concentration after admission. ${ }^{11}{ }^{13}$ Criteria for surgery were seldom stated, but most operations were occasioned by severe continued or recurrent haemorrhage. In one study operations were included in a definition of "treatment failure" and could not be analysed separately. ${ }^{6}$

\section{STATISTICS}

For each trial the outcomes of the intervention were expressed as the ratios of the odds of the events (rebleeding, operation, or death) in patients assigned to tranexamic acid to the odds of these events in patients assigned to placebo. $95 \%$ Confidence intervals for the individual odds ratios were calculated by an exact method. ${ }^{18}$ We used two techniques for pooling the data. The method of Peto ${ }^{19}$ which is a modified Mantel-Haenszel procedure, has been widely used and was employed by Collins and Langman in their metaanalysis of the trials of histamine $\mathrm{H}_{2}$ receptor antagonists in upper gastrointestinal haemorrhage. ${ }^{5}$ The technique assumes a constant effect across studies, the only variation in the observed effects being due to sampling error, and provides an overall outcome measure, the pooled odds ratio, and a separate test for heterogeneity of outcome. If there is heterogeneity in the treatment effects across the trials the MantelHaenszel method of obtaining a summary odds ratio may not be appropriate.

An alternative approach based on the random effects model has been proposed by DerSimonian and Laird. ${ }^{20}$ With this model the observed treatment effect for each study is partitioned into two components - the "true" treatment effect and sampling error. The true treatment effect for a study will depend on several factors, such as the selection of patients, design and conduct, and definition of outcomes. This effect can be thought of as a composite of the mean effect for the population of possible studies that could be conducted (from which the studies being included in the meta-analysis were sampled) and the deviation of the study's true effect from the population mean. If there is no heterogeneity across the studies all the deviations will be zero. The variance of the deviation terms is a measure of the heterogeneity in the treatment effects which may be incorporated into the estimate of the overall treatment effect.

An adaptation of the procedure proposed by DerSimonian and Laird to estimate the overall treatment effect, and to test for heterogeneity, was used with the logarithm of the odds ratio as the effect measure. An estimate of the pooled odds ratio was obtained by exponentiating the logarithm of the pooled odds ratio. When the treatment effects are constant across studies the estimate of the weighted odds ratio is equivalent to that proposed by Woolf. ${ }^{21}$ A measure of any heterogeneity is incorporated into the weights used in the calculation of the overall odds ratio. A test of significance was performed by comparing the $Z$ statistic, calculated as the logarithm of the estimated odds ratio divided by its standard error (SE), with the standard normal distribution. An approximate $95 \%$ confidence interval was obtained by taking exponentials of the confidence limits calculated from the log of the estimated odds ratio and 1.96 times its SE.

\section{Results}

Table III shows the outcome measures in the individual trials. The analyses include information on 55 patients withdrawn after randomisation and omitted from the original trial reports, and in all but one study they represent analyses by intention to treat. Most of the individual odds ratios were less than one, indicating possible benefit from tranexamic acid. Nevertheless, in 13 of the 17 individual trial outcomes the $95 \%$ confidence intervals included unity.

With the method of Peto ${ }^{19}$ the pooled analyses suggested that treatment with tranexamic acid resulted in roughly a $20 \%$ reduction (estimated pooled odds ratio 0.80 ) in the incidence of rebleeding, a $30 \%$ reduction (estimated pooled odds ratio 0.72 ) in the need for emergency surgery, and a $40 \%$ reduction (estimated pooled odds ratio 0.60 ) in mortality (table IV). The reductions in operation rate and mortality achieved conventional levels of significance $(p<0.05)$. Heterogeneity in outcomes was evident in the cases of rebleeding and operation rates. Because of this the data were reworked by using the random effects model. The results indicated roughly a $30 \%$ reduction in the occurrence of rebleeding with tranexamic acid and roughly $40 \%$ reductions in operation rate and mortality (table IV). As with Peto's method, the reduction in mortality was significant. The estimated effects of tranexamic acid on mortality were homogeneous when tested by both methods, and predictably the pooled odds ratio with its confidence interval was unchanged when recalculated by the method of DerSimonian and Laird. ${ }^{20}$

Reanalysis of the data from those patients who completed their treatments (573 tranexamic acid, 567 
placebo) produced similar trends to those seen in the analyses by intention to treat. By the method of Peto ${ }^{19}$ the estimated odds ratios ( $95 \%$ confidence intervals) were: for rebleeding $0.75(0.56$ to $1.00 ; p=0.05)$, for operation $0.69(0.49$ to $0.96 ; p=0.027)$, and for mortality $0.54(0.34$ to $0.85 ; p=0.008)$. By the method of DerSimonian and Laird ${ }^{20}$ the estimated odds ratios were: for rebleeding $0.69(0.46$ to $1.00 ; p=0.07)$, for operation $0.53(0.24$ to $1.20 ; p=0.12)$, and for mortality $0.54(0.33$ to $0.88 ; \mathrm{p}=0.01)$.

Other evidence of benefit-In two trials the average total transfusion requirement was significantly reduced in patients given the active treatment ${ }^{613}$ and in two trials the transfusion requirement was significantly lower on particular days after admission to hospital..$^{79}$ One trial found no difference and the other a slight increase in the units of blood received by treated patients. ${ }^{1011}$ Because of inconsistencies in the reporting of results these data were not included in the meta-analyses.

Side effects of treatment-Adverse events reported in patients given tranexamic acid were one cerebral infarct, two myocardial infarcts, two episodes of pulmonary embolism, one deep vein thrombosis, and five cases of superficial thrombophlebitis. By comparison two cerebral infarcts and two episodes of thrombophlebitis were reported in patients given placebo. One event possibly associated with tranexamic acid was reported as fatal. The patient, a man, had a transient cerebral ischaemic attack followed by a fatal stroke five days after discharge from hospital. He also had polycythaemia requiring venesection.

\section{Discussion}

These results indicate that tranexamic acid given for upper gastrointestinal haemorrhage may result in worthwhile reductions in the frequency of continued or recurrent haemorrhage, the need for urgent surgery, and mortality. A benefit of treatment was apparent when the data were analysed on the basis of intention to treat and remained when the analyses were confined to patients who completed their treatment. Though the total number of subjects included in this meta-analysis was less than half that included in the study by Collins and Langman evaluating histamine $\mathrm{H}_{2}$ receptor antagonists in upper gastrointestinal haemorrhage, the estimated treatment effects appeared to be similar. ${ }^{5}$

Tranexamic acid has a plausible mode of action in upper gastrointestinal haemorrhage. It is an inhibitor of plasminogen, and plasminogen activators have been found in the gastric and duodenal mucosa. ${ }^{22}$ High activities of plasmin have been detected in the gastric venous effluent of patients with peptic ulcers. ${ }^{23}$ Aminocaproic acid, which has a similar action to tranexamic acid, inhibits the release of plasmin. ${ }^{24}$ In addition, tranexamic acid has been shown to inhibit the fibrinolytic action of pepsin..$^{25}$ This effect is independent of changes in $\mathrm{pH}$, which may have particular relevance for patients who are critically ill and whose gastric contents may remain acidic despite treatment with histamine $\mathrm{H}_{2}$ receptor antagonists. ${ }^{26}$

In contrast with $\mathrm{H}_{2}$ antagonists, which are given to most patients after an episode of gastrointestinal bleeding, tranexamic acid appears to be used rarely by gastroenterologists. ${ }^{8}$ There are several possible explanations. Histamine $\mathrm{H}_{2}$ receptor antagonists are prescribed widely after upper gastrointestinal haemorrhage, probably because they heal ulcerated lesions rather than because of faith in their modest effects in reducing the rate of recurrent haemorrhage and death. In contrast, tranexamic acid has no proved ulcer healing effect and is not given unless it is thought likely to improve the short term outlook after an episode of bleeding. Probably the lack of popularity of tranexamic acid for upper gastrointestinal haemorrhage is due to a widespread belief that it is inefficacious. Of the six trials included in this meta-analysis, only one was large enough to detect a reduction in mortality. In the study by Barer et al mortality was reduced by over $50 \%$ but there were no parallel reductions in the rates of rebleeding and need for operative intervention. " This lack of internal consistency may have contributed to doubts that have been expressed about the benefits of tranexamic acid. ${ }^{27} 28$ As our analyses show, treatment may reduce the likelihood of repeated haemorrhage and the need for surgery. The trends, however, were not as strong as in the case of mortality.

Another factor which may have limited the use of tranexamic acid is concern about toxicity. In subarachnoid haemorrhage the benefits of the drug in terms of reduced mortality from rebleeding were offset by a larger number of deaths from cerebral infarction in the treated group. ${ }^{29}$ Though reporting of adverse events such as thrombosis may have been incomplete in the trials of tranexamic acid for upper gastrointestinal haemorrhage, our analyses of mortality included all deaths occurring during that hospital admission, irrespective of cause, and treatment was associated with an overall benefit.

Our analyses highlighted some heterogeneity in the outcomes of the trials of tranexamic acid, particularly in the case of operation rates. There are several possible reasons. There was considerable variation in the case mix included in the trials, in particular the proportion of patients who had clinical shock at entry. The trials were conducted in three countries and treatment regimens varied, tranexamic acid being given intravenously or by mouth in different doses. There were also differences in the definitions of rebleeding and the criteria for surgical intervention. There might have been less heterogeneity had we been able to analyse the outcomes in the different diagnostic subgroups. Because of the greater statistical power of Collins and Langman's meta-analysis of the trials of histamine $\mathrm{H}_{2}$ receptor antagonists they were able to examine subsets and showed significant reductions in the rates of rebleeding, operation, and death in patients bleeding from gastric ulcers but not in those bleeding from duodenal ulcers. ${ }^{5}$ The effects were homogeneous in the group with gastric ulcer. ${ }^{5}$ Because of smaller numbers and incomplete reporting of some trials we could not analyse the results from diagnostic subsets.

The extent to which heterogeneity should influence interpretation of the findings of meta-analyses is controversial. In some studies data showing heterogeneity in outcome have been presented but seem to have made little difference to the interpretation of results. ${ }^{50}$ Others have argued that if appreciable heterogeneity is detected it may be inappropriate to use a statistical method which assumes that the underlying treatment effect is constant across the various studies. ${ }^{20}$ In this study we included an analysis which incorporated a measure of heterogeneity in the pooled outcome analysis, but this made little difference to our interpretation of the results.

There are other reasons for regarding the results of meta-analyses with caution. Sacks et al have outlined some important considerations. ${ }^{4}$ They emphasised the importance of minimising certain sources of bias, including selection bias, data extraction bias, and publication bias. In this study there were few opportunities for selection bias, as all but one of the randomised controlled clinical trials of fibrinolytic inhibitors in gastrointestinal haemorrhage were included. The remaining trial was excluded because the patients received several other possibly active compounds in addition to aminocaproic acid. ${ }^{17}$ That trial, however, was a positive trial so that its exclusion 
would not have biased the meta-analysis in favour of active treatment. The likelihood of data extraction bias is small, as the endpoint frequencies used in the analysis vere those published by the authors, in some cases supplemented by data on patients withdrawn after randomisation. Though data were not extracted blind in respect of the treatment assigned (the ideal suggested by Sacks $e t a l^{4}$ ), editing did not take place before their inclusion in the analysis.

Publication bias - that is, the preferential publication of positive studies - remains the main threat to the validity of this or any other meta-analysis. Using the example of ovarian cancer, Simes has shown that a pooled analysis of the results of trials registered with an international data bank provided a more conservative estimate of the benefits of combination chemotherapy than a pooled analysis of only those studies which had been published..$^{31}$ In a recent review Begg and Berlin emphasised the importance of considering publication bias when interpreting the findings of meta-analyses. ${ }^{32}$ They reviewed several contributory factors including sample size, which is likely to be important in the case of drug trials in gastrointestinal bleeding.

Whereas large trials possibly comprising thousands of patients will provide precise estimates of size of effect and are highly likely to be published even if they are negative, small negative trials are less likely to be submitted or accepted for publication. In this regard it is worrying that trials of new treatments for gastrointestinal bleeding have, in general, been small. For instance, the average number of patients assigned to treatment with tranexamic acid was 105 , and in the meta-analysis of the trials of histamine $\mathrm{H}_{2}$ receptor antagonists in upper gastrointestinal haemorrhage the average number of patients assigned to active treatment was only $50 .{ }^{5}$ Given the requirement for sample sizes in the thousands in order to detect small but clinically important reductions in the mortality from upper gastrointestinal haemorrhage, it is easy to see how a number of small negative trials could be regarded as inadequate by referees or journal editors and remain unpublished. The magnitude of this type of publication bias will depend on how the results of individual trials are perceived. Given the small size of the effects noted in the individual trials of tranexamic acid, these were interpreted in a surprisingly positive way by the authors, some of whom were influenced by other factors, particularly an apparent reduction in transfusion requirements in treated patients. It is very difficult for us to make adjustments for these unknown biases, and the results of this analysis must therefore be applied with caution.

The evidence presented here raises important issues regarding the optimum management of patients at high risk after admission to hospital with an episode of acute upper gastrointestinal haemorrhage. Tranexamic acid may be of benefit and treatment is cheap. The cost of a week's treatment in an Australian public hospital is around \$A 40. It is interesting to speculate whether there might be an additional benefit if tranexamic acid was used in combination with a histamine $\mathrm{H}_{2}$ antagonist, antacids, or a proton pump inhibitor. Theoretically, there may be advantages in adding a plasminogen inactivator to treatment aimed at raising the intragastric $\mathrm{pH}$ to a level at which pepsin is completely inactivated. ${ }^{33}$ An additive effect of clinical importance could be confirmed only by well controlled randomised trials of adequate size and factorial design. ${ }^{34}$ Attention has already been drawn to the urgent need for large randomised clinical trials in upper gastrointestinal haemorrhage, which, as in trials in myocardial infarction, should have survival as their main end point. ${ }^{5}$ Our study reinforces this call and provides estimates of size of effect, which would be valuable in the planning of definitive trials.

We thank Kabivitrum for help with the library search and the investigators who responded to our requests for additional data.

1 Langman MJS. Upper gastrointestinal bleeding: the trials of trials. Gut 1985;26:217-20.

2 ISIS-1 (First International Study of Infarct Survival) Collaborative Group. Randomised trial of intravenous atenolol among 16027 cases of suspected acute myocardial infarction. Lancet 1986;ii:57-66.

3 Gruppo Italiano per lo Studio della Streptochinasi nell'Infarto Miocardico (GISSI). Effectiveness of intravenous thrombolytic treatment in acute
(a) myocardial infarction. Lancet 1986;i:397-402.

4 Sacks HS, Berrier J, Reitman D, et al. Meta-analysis of randomized controlled trials. N Engl I Med 1987;316:450-5.

5 Collins $R$, Langman $M$. Treatment with histamine $\mathrm{H}_{2}$ antagonists in acute upper gastrointestinal hemorrhage. $N$ Engl f Med 1985;313:660-6.

6 Cormack F, Chakrabarti RR, Jouhar AJ, Fearnley GR. Tranexamic acid in upper gastrointestinal haemorrhage. Lancet 1973;i:1207-8.

7 Biggs JC, Hugh TB, Dodds AJ. Tranexamic acid and upper gastrointestina haemorrhage - a double blind trial. Gut 1976;17:729-34

8 Gilbert DA, Persing J, Silverstein FE, et al. National ASGE survey on upper gastrointestinal bleeding - multivariate analysis of predictors of outcome. Gastrointest Endosc 1982;28:150-1.

9 Engqvist A, Brostrom O, v Feilitzen F, et al. Tranexamic acid in massive haemorrhage from the upper gastrointestinal tract: a double blind study. Scand f Gastroenterol 1979;14:173-8.

10 Bergqvist D, Dahlgren S, Hessman Y. Local inhibition of the fibrinolytic system in patients with massive upper gastrointestinal haemorrhage. system in patients with masi

11 Barer D, Ogilvie A, Henry D, et al. Cimetidine and tranexamic acid in the treatment of acute upper gastrointestinal tract bleeding. $N$ Engl f Med 1983;308:1571-5.

12 Bromster D, Brostrom O, Engqvist A, et al. Tranexamsaure bei groben magenblutungen - eine doppelblindstudie. Aktuelle Gastrologie 1977;6: 225-8.

13 Stael von Holstein C, Eriksson SB, Kallen R. Tranexamic acid as an aid to reducing blood transfusion requirements in gastric and duodenal bleeding. Br Med F 1987;294:7-10.

14 Osterberg HO, Ulfberg J, Wennerholm M, Zellner K. Acute gastrointestinal haemorrhage. Experience with early panendoscopy and tranexamic acid in a rural hospital. Acta Chir Scand 1977;143:464-8.

15 Cronsted J, Osterberg H, Carling L, et al. Diagnosis and treatment of acute gastrointestinal haemorrhage in a small disrict hospital. Acta Med Scand 1976;199:129-32.

16 Avanzi G. Attivita antifibrinolitica ed antiemorragica dell'acido transaminometil-cicloesano-carbossilico. Minerva Med 1972;63:4758-66.

17 Pascal J-P, Tournut R, Clanet J, et al. Treatment hemostatique des hemorragies digestives hautes (hypertension portale exceptee) per perfusion astriquee. Resultats d'une etude controlee. Gastroenterol Clin Biol 1978;2: 357-64.

18 Thomas DG. Exact confidence limits for an odds ratio in a $2 \times 2$ table. Applied Statistics 1971;20:105-10.

19 Yusuf S, Peto R, Lewis J, et al. Beta blockade during and after myocardial infarction: an overview of the randomized trials. Prog Cardiovasc Dis 1985;27:335-71.

20 DerSimonian R, Laird N. Meta-analysis in clinical trials. Controlled Clin Trials 1986;7:177-88

21 Woolf B. On estimating the relation between blood group and disease. Ann Hum Genet 1955; 19:251-3.

22 Cox HT, Poller L, Thomson JM. Gastric fibrinolysis: a possible aetiological link with peptic ulcer. Lancet 1967; i:1300-2.

$23 \mathrm{Cox}$ HT, Poller L, Thomson JM. Evidence for the release of gastric fibrinolytic activity into peripheral blood. Gut 1969;10:404-7.

24 Thomson JM, Turner L, Poller L. Inhibition of gastric plasmin activity by epsilon-aminocaproic acid. Ann $R$ Coll Surg Engl 1973;53:340-7.

25 Low J, Dodds AJ, Biggs JC. Fibrinolytic activity of gastroduodenal secretions-a possible role in upper gastrointestinal hemorrhage. secretions - a possible role
Thromb Res 1980;17:819-30.

26 More DG, Raper RF, Munro IA, et al. Randomized prospective trial of cimetidine and ranitidine for control of intragastric $\mathrm{pH}$ in the critically ill. Surgery 1985;97:215-24.

27 Anonymous. Does drug therapy prevent recurrent bleeding from peptic ulcers? [Editorial]. Drug Ther Bull 1984;22:90-2.

28 Anonymous. Bleeding ulcers: scope for improvement? [Editorial]. Lancet 1984;i:715-7.

29 Venueulen M, Lindsay KW, Murray GD, et al. Antifibrinolytic treatment in subarachnoid hemorrhage. $N$ Engl f Med 1984;311:432-7.

30 Collins R, Scrimgeour A, Yusuf S, Peto R. Reduction in fatal pulmonary embolism and venous thrombosis by perioperative administation of subcutaneous heparin. N Engl F Med 1988;318:1162-73.

31 Simes RJ. Confronting publication bias: a cohort design for meta-analysis. Stat Med 1987;6:11-29.

32 Begg CB, Berlin JA. Publication bias: a problem in interpreting medical data. Journal of the Royal Statistical Society 1988;151:419-63.

33 Berstad A. Management of acute upper gastrointestinal bleeding. Scand $\mathcal{J}$ Gastroenterol 1982;75(suppl):103-8.

34 Chalmers TC. Cimetidine and tranexamic acid for upper gastrointestinal tract bleeding. N Engl f Med 1983;309:1328.

(Accepted 14 February 1989) 